\title{
Pemanfaatan Limbah Plastik Menjadi Ecobricks Di Kampung Ayapo, Kabupaten Jayapura, Papua
}

\author{
Henderite Loisa Ohee $^{1^{*}}$, Henderina Josefina Keiluhu ${ }^{1}$ \\ ${ }^{1}$ Jurusan Biologi, Fakultas MIPA, Universitas Cenderawasih \\ Jl. Kamp. Wolker, Kampus Baru Waena, 99358, Jayapura, Papua, henderite.ohee@ gmail.com \\ Penulis korespondensi: Henderite L. Ohee, Email: henderite.ohee@gmail.com
}

\begin{abstract}
ABSTRAK
Sampah plastik banyak ditemukan di Danau Sentani. Untuk mengurangi dan menggunakan kembali sampah plastik, kami berinisiatif memperkenalkan ecobrick kepada anak-anak usia 6-17 tahun. Pelatihan Ecobricks diberikan di Desa Ayapo, Kabupaten Jayapura, Papua selama 5 - 12 Oktober 2020. Botol plastik dengan merek dan ukuran yang sama, tongkat kayu, kemasan plastik, gunting dan timbangan merupakan alat yang digunakan untuk membuat eco-bricks. Ada rangkaian proses kegiatan ecobrick: memperlihatkan alat, memperagakan dan mempersilakan anak membuatnya. Usai pelatihan, anak-anak melanjutkan membuat eco-bricks di rumahnya secara mandiri. Mereka mengumpulkan, mencuci, mengeringkan, memotong dan memasukkan sampah plastik yang mereka temukan di Desa Ayapo ke dalam botol. Sampah plastik tersebut kemudian dipres dengan padat sehingga botol air mineral ukuran $600 \mathrm{ml}$ mencapai berat 200 gram. Kemudian mereka memberi label pada botol dengan nama, tanggal dan beratnya. Anak-anak bisa membuat lebih dari satu botol ecobrick per kelompok dalam seminggu. Kelompok yang telah mengumpulkan setidaknya 12 botol mampu membuat kluster bangku modular. Dapat disimpulkan bahwa ecobrick adalah cara terbaik untuk memanfaatkan sampah plastik agar tidak membahayakan biota dan manusia.
\end{abstract}

Kata kunci: ecobricks, Danau Sentani, sampah plastik, pelatihan

\begin{abstract}
Plastic waste is abundantly found in Lake Sentani. To reduce and reuse plastic waste, we initiated to introduce ecobricks to children of 6-17 years of age. Ecobricks training was given in Ayapo Village, Jayapura Regency, Papua during 5 - 12 October 2020. Plastic bottles of the same brand and size, wooden sticks, plastic packaging, scissors and balance are the tools used to make eco-bricks. There were a series of ecobricks activity processes: showing the tools, demonstrating and letting the children to make it. After the training, the children continued to make eco-bricks in their homes independently. They collected, washed, dried, cut and put plastic waste they found in Ayapo Village into the bottles. The plastic waste was then solidly pressed to make the $600 \mathrm{ml}$ mineral water bottle reached 200 grams of weight. Then they labelled the bottle with their name, date and weight. The children might make more than one bottle of eco-brick per group in a week. Groups that had collected at least 12 bottles were able to make a modular cluster of a bench. It is concluded that ecobricks are an excellent way to utilize plastic waste to avoid endaring both biota and humans.
\end{abstract}

Keywords: ecobricks, Lake Sentani, plastic waste, training 


\section{PENDAHULUAN Analisis situasi}

Danau Sentani adalah danau dataran rendah terbesar di Papua. Danau ini memiliki tingkat endemisitas yang tinggi (Polhemus, et al. 2004), dan salah satu daerah prioritas untuk konservasi ekosistem perairan tawar menurut (Conservation International, 1999). Sepuluh tahun belakangn ini, tekanan terhadap Danau Sentani berasal sangat besar yang berasal dari aktivitas penduduk di dan sekitar Danau Sentani. Sekitar $60 \%$ dari wilayah danau ditempati oleh manusia, yang umumnya bekerja sebagai nelayan yang menempati 24 kampung yang menyebar di sepanjang pantai dan pulau-pulau kecil di dan sekitar danau (Umar et al. 2005, BAPEDALDA Provinsi Papua dan LPPM-ITB 2004). Salah satu aktivitas manusia yang cukup tinggi intensitasnya belakangan ini adalah memanfaatkan Danau Sentani sebagai tempat sampah besar, sehingga ditemukan limbah rumah tangga atau limbah dari berbagai aktivitas manusia lainnya di perairan dan daratan sekitarnya, yang berasal pemukiman dan fasilitas umum di sekeliling danau maupun dari kampung - kampung di danau. Pembuangan sampah organik dan anorganik secara sembarang ke lingkungan menyebabkan perubahan yang signifikan terhadap lingkungan dan biota Danau Sentani. Sampah organik dan anorganik terbawa ke danau dan mencemari perairan danau dan merusak habitat organisme. Ohee (2013), Ngamelubun (2017), Ohee et al. (2018) menemukan bahwa Danau Sentani telah tercemar oleh bahan-bahan organik di beberapa lokasi di danau.

Meningkatnya jumlah penduduk di kampung dan distrik sekitar Danau Sentani, juga meningkatkan jumlah limbah organik dan anorganik yang masuk ke Danau Sentani. Akibatnya, kualitas habitat biota danau menurun. Salah satu jenis limbah anorganik yang dijumpai sangat banyak di danau dan sekitarnya adalah sampah plastik. Berdasarkan kemampuan diurai oleh alam (biodegradability), plastik digolongkan sebagai sampah non-biodegradable, artinya tidak dapat diuraikan secara proses biologi. Oleh karena itu sampah pelastik yang dibuang di darat dan perairan Danau Sentani akan ada disana sampai kapanpun. Hal ini tentu saja menganggu dan mengancam habitat biota Danau Sentani. Umumnya, pemusnahan plastik yang dilakukan masyarakat adalah dengan dibakar. Jika plastik dibakar maka akan menghasilkan molekul beracun dioxin yang berbahaya bagi manusia dan keanekaragaman hayati karena akan kembali ke alam. Tetapi, sampah plastik termasuk golongan sampah yang dapat diolah dan digunakan kembali (recyclable) karena memiliki nilai secara ekonomi. Dengan demikian, sampah plastik yang ada di lingkungan Danau Sentani dapat diambil dan dimanfaatkan kembali menjadi benda-benda bernilai ekonomi dan bermanfaat kembali bagi manusia ("Global Ecobricks Alliance," n.d.).

\section{Tujuan dan Manfaat Kegiatan}

Oleh karena itu, pada pengabdian ini sampah plastik (botol mineral dan plastik kemasan makanan, deterjen dan lain-lain) dimanfaatkan menjadi ecobricks. Pengenalan ecobricks dan pelatihan pembuatannya diberikan dengan tujuan agar plastik tidak dibuang ke alam (danau) atau yang ada di danau dikumpulkan dan dimanfaakan menjadi ecobricks. Dengan demikian, diharapkan limbah plastik berkurang di danau, khususnya di Kampung Ayapo, walaupun jumlahnya sangat kecil. Ecobricks dapat membantu mengurangi sampah plastik yang dibuang ke alam dan tidak dibakar, sehingga mengurangi ancaman polusi limbah pelastik bagi biota di danau, mengurangi bahayanya bagi manusia serta menghasilkan produk yang bermanfaat bagi kehidupan.

\section{METODE PELAKSANAAN}

\section{Sasaran Kegiatan}

Sasaran kegiatan pengabdian ini adalah anak-anak usia 6-17 tahun di Kampung Ayapo, Distrik Sentani Timur, Kabupaten Jayapura, Provinsi Papua. Kelompok anak-anak ini secara rutin dibina oleh pelaksana dalam beberapa kali pengabdian yang berkaitan dengan konservasi Danau Sentani, pemanfaatan sampah baik organik maupun anorganik sejak tahun 2015/2016. Target kegiatan ini adalah limbah plastik di Kampung Ayapo dimanfaatkan menjadi ecobricks dan mengurangi pemusnahan dengan cara dibakar karena akan menghasilkan molekul beracun dan berbahaya bagi manusia dan alam.

\section{Lokasi Kegiatan}

Pelatihan pembuatan ecobricks dilaksanakan di Kampung Ayapo, Distrik Sentani Timur, Kabupaten Jayapura, Provinsi Papua. 


\section{Metode yang digunakan}

Pelatihan pembuatan ecobricks dilakukan dengan tahap-tahapan sebagai berikut: 1) Pre Test: tentang sampah plastik dan bahayanya, serta cara pembuatan ecobricks. Test diberikan dalam bentuk permainan. Kemudian kegiatan dilanjutkan dengan 2) Seminar : tentang bahaya sampah plastik. Pada seminar ini dijelaskan tentang jenis-jenis sampah dan bahayanya, secara khusus tentang sampah plastik. Setelah seminar, dilanjutkan dengan 3) pelatihan pembuatan ecobricks. Pelatihan dilakukan dengan memaparkan alat dan bahan yang dibutuhkan untuk pembuatan ecobricks, memberikan contoh pembuatan ecobricks dan diikuti oleh anak-anak peserta pelatihan. Alat dan bahan yang digunakan adalah: sampah plastik (kantong plastik, plastik paket makanan/deterjen, sterofoam, sedotan), botol air mineral (600 ml atau 1,5 L), merek botol harus sama, gunting, stik kayu (jangan gunakan besi atau bahan lainnya), timbangan, spons, sabun, lap kering dan selotip bening ukuran besar. 4) Pengumpulan sampah. Sampah plastik dan botol mineral dikumpulkan dari lingkungan di Kampung Ayapo (dilakukan oleh anak-anak). Setelah itu, sampah dibersihkan dan dikeringkan. Selanjutnya 5) Pembuatan ecobricks. Anak-anak membuat ecobricks dalam tujuh kelompok yang telah dibagi berdasarkan lokasi tempat tinggal di Kampung Ayapo selama satu minggu, 6-11 Oktober 2020, setelah pertemuan I, 5 Oktober 2020, dan sebelum pelaksanaan pelatihan hari kedua yaitu 12 Oktober 2020. Pada tanggal ini pula, pelaksana dan anak-anak menimbang ecobricks yang telah dibuat oleh anak-anak di rumah. Anak-anak melanjutkannya mengisi plastik di botol-botol yang beratnya belum mencapai 200 gram. Pada tahap akhir pengabdian dilaksanakan 6) post-test dengan soal yang sama dengan soal pre test dan juga dalam bentuk permainan. Hasil pengabdian dijelaskan secara deskriptif dan didukung oleh teori dan hasil-hasil penelitian yang relefan.

\section{HASIL DAN PEMBAHASAN}

\section{Sampah plastik}

Penggolongan sampah organik dan anorganik, dan secara khusus tentang sampah plastik dan bahayanya disampaikan kepada anak-anak di Kampung Ayapo dalam bentuk seminar dan tanya-jawab. Sebelumnya, melalui dana BOPTN LPPM UNCEN 2015, pelaksana telah melakukan pengabdian tentang penggolongan dan jenis-jenis sampah kepada mitra yang sama, sehingga anak-anak yang pernah menerima informasi tersebut dapat mengingatnya. Pada pengabdian ini yang menjadi penekanan adalah sampah plastik dan bahayanya. Plastik telah menjadi masalah dunia dan sangat berbahaya bagi hewan dan manusia, termasuk masyarakat dan biota di Danau Sentani. Berbagai jenis hewan di ekosistem perairan laut seperti burung, penyu yang mati karena menelan atau terlilit sampah pelastik (Gall \& Thompson, 2015, Wilcox, et al. 2015) (Gambar 1), yang dapat saja terjadi juga terhadap berbagai organisme di Danau Sentani. Polusi plastik menyebabkan kerusakan secara ekologi dan mengakibatkan efek yang buruk terhadap lingkungan laut (Ilyas et al. 2018). Lebih dari pada itu, limbah plastik juga menghasilkan komponen racun yang berbahaya bagi manusia, apalagi ketika dibakar akan menghasilkan molekul beracun yang dapat menyebabkan berbagai penyakit (Ilyas et al., 2018, Verma et al., 2016).
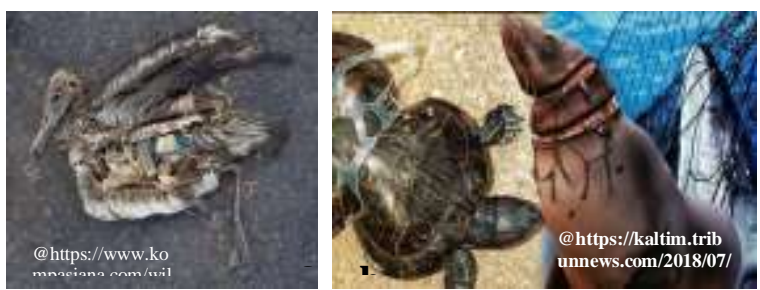

Gambar 1. Contoh-contoh bahaya plastik bagi hewan. Plastik yang tertelan oleh burung (a), penyu dan anjing laut yang terlilit plastik (b).

Sumber sampah plastik di perairan laut adalah $80 \%$ dari aktivitas di daratan, sedangkan aktivitas di laut menyumbang hanya $20 \%$. Polusi limbah plastik di perairan tawar tidak banyak dilaporkan, kebalikan dengan ekosistem perairan laut. Namun, hal ini kemungkinan terjadi di Danau Sentani. Walaupun penelitian secara ilmiah belum pernah dilakukan, namun sebagian besar sampah, khususnya sampah plastik di Danau Sentani berasal dari berbagai aktivitas dari daratan sekitarnya, seperti Sentani, Waena yang populasi manusianya tinggi (Badan Pusat Statistik (BPS) Kabupaten Jayapura, 2018). Cable et al. (2017) melaporkan polusi plastik di 
Great Lakes, Amerika diperkirakan mencapai dua juta partikel $\mathrm{km}^{-2}$.

Limbah plastik yang dibuang ke alam akan terurai menjadi mikroplastik yang berukuran sangat kecil, <5mm, yang bahkan dapat dicerna oleh makhluk sekecil invertebrata yang sangat kecil. Mikroplastik ini berasal dari berbagai aktivitas manusia seperti aktivitas sehari-hari sampai pembuangan tidak sengaja dari proses produksi di darat maupun di laut (Galafassi et al. 2019). Jumlah sampah plastik yang terpecah menjadi mikroplastik dan masuk ekosistem perairan laut tinggi dari tahun ke tahun (van Sebille et al., 2015, Jambeck et al., 2015, Lebreton \& Andrady, 2019). Di tahun 2050 kemungkinan 1200 juta Metric ton (Mt) akan berakhir di TPA atau lingkungan alami, 9000 Mt akan di daur ulang, 1200 Mt akan dibakar jika tren produki dan pengelolaan limbah sama seperti sekarang (Geyer, et al. 2017). Asia merupakan benua di dunia yang paling tinggi salah mengelola limbah pelastik, dimana China dan India adalah dua negara dengan jumlah tertinggi membuang sampah plastik ke lingkungan (Lebreton \& Andrady, 2019). Laporan lain menyebutkan Indonesia menjadi negara urutan kedua dari 20 negara di dunia setelah China yang pengelolaan limbah plastiknya tidak tepat (Jambeck et al., 2015). Dikuatirkan, semakin banyak limbah plastik yang masuk ke Danau Sentani, maka danau ini semakin tercemar oleh mikroplastik yang akhirnya bisa masuk ke rantai makanan di Danau dan berakhir di manusia.

Beberapa cara intervensi pengelolaan limbah padat dapat dilakukan. Misalnya, koleksi dan mendaur ulang sampah langsung dari konsumen dan poin yang diperoleh dapat ditukarkan dengan kebutuhan sehari-hari. Aktivitas inipun sekaligus menyediakan pekerjaan bagi penduduk yang mengoleksi sampah tersebut. Intervensi lain adalah memilah sampah, dimana sampah organik kemudian diolah menjadi kompos berkualitas bagus yang dimanfaatkan oleh petani lokal, dan sampah anorganik dijual ke industri daur ulang atau didaur ulang menjadi tumbler dari botol yang dapat didaur ulang dan berbagai intervensi lainnya yang dapat dilakukan (Jambeck et al., 2018). Selanjutnya, Ilyas et al. (2018) menganjurkan lima strategi yaitu daur ulang, yaitu dibuang ke TPA, pembakaran, penguraian dengan mikroba dan mengubahnya menjadi material yang bermanfaat. Masing-masing cara ini mempunyai keterbatasan. Tetapi, sebenarnya limbah plastik dapat digunakan kembali menjadi berbagai berbagai produk yang bermanfaat bagi manusia, misalnya digunakan untuk membuat jalan, bahan bakar (Newaj \& Masud, 2014), termasuk menjadi ecobricks.

\section{Pelatihan Pembuatan Ecobricks}

Pengelolaan limbah plastik yang tepat akan mengurangi masalah polusi limbah plastik di alam. Selain dibuang ke TPA, dimanfaatkan kembali menjadi bahan bakar, material untuk jalan dan produk lainnya sebaiknya dilakukan untuk mengurangi poluasi plastik di lingkungan. Salah satunya adalah memanfaatkan botol plastik dan plastik kemasan makan, deterjen dan lainnya menjadi ecobrick. Pemanfaatan plastik menjadi ecobricks belum banyak dilakukan di kampung-kampung di Danau Sentani, yang merupakan salah satu ekosistem air tawar penting di Papua. Sejauh ini, limbah plastik di lokasi perumahan di kampung-kampung di Danau Sentani dibakar atau dibiarkan saja di perairan, yang kemungkinan akan menimbulkan masalah terhadap organisme dan manusia suatu saat nanti. Oleh karena itu, pada pengabdian ini limbah plastik di sekeliling kampung Ayapo, Kabupaten Jayapura dikumpulkan, dibersihkan dan dikeringkan (Gambar 4) dan kemudian dibuat menjadi ecobricks. Pelatihan ini diberikan kepada anakanak usia $6-17$ tahun. Tahapan-tahapan pelatihan pembuatan ecobricks:

1. Memperkenalkan alat dan bahan pembuatan ecobricks (Gambar 2)
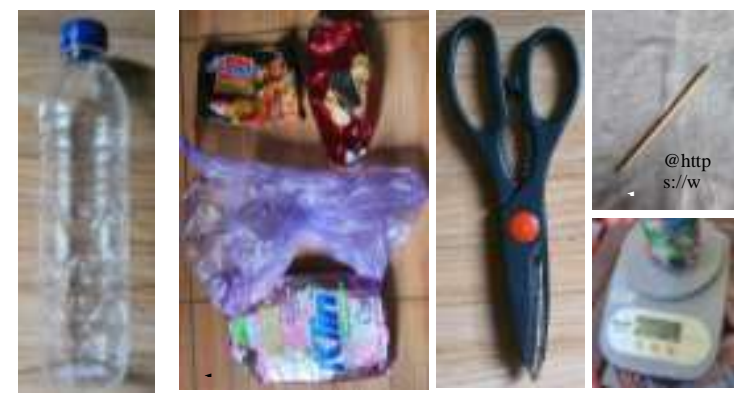

Gambar 2. Alat dan bahan untuk membuat ecobricks, botol air mineral (a), sampah plastik (kemasan makanan/detergen, kantong plastik, dll) (b), gunting (c), stik kayu (d) dan timbangan (e). 
2. Menjelaskan cara membuat ecobricks dan mempraktekannya kepada anak-anak (Gambar 3).
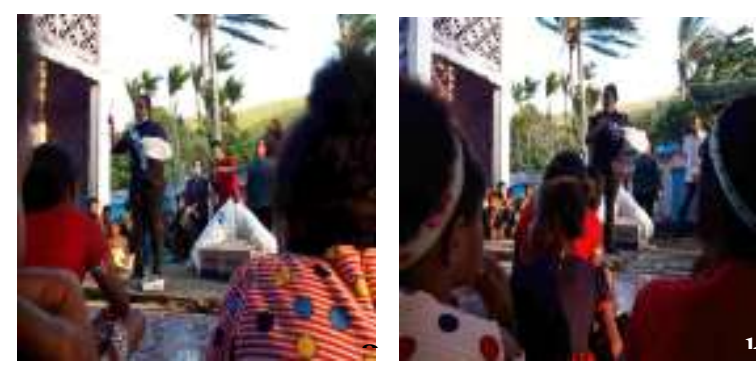

Gambar 3. Pelaksana menunjukkan alat dan bahan yang dibutuhkan untuk ecobricks (a) dan menjelaskan cara membuat ecobricks (b)

1) Sampah plastik dicuci bersih menggunakan spons dan sabun, dikeringkan dan dipotong kecil-kecil. Sampah kantong plastik di sobek-sobek dengan ukuran sedang (Gambar 4)

2) Botol air mineral dicuci bersih dan dikeringkan. Merek botol yang digunakan harus sama.
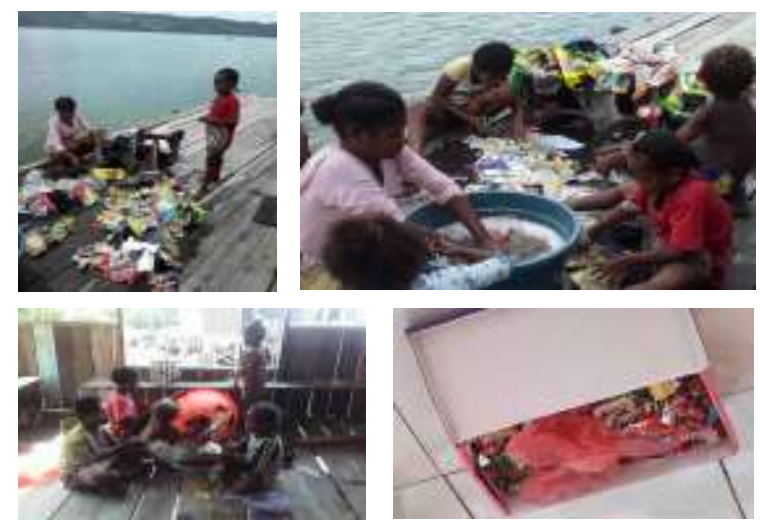

Gambar 4. Sampah plastik yang dikumpulkan dari danau dicuci sampai bersih menggunakan $\operatorname{sabun}(\mathrm{a}, \quad \mathrm{b})$, dikeringkan menggunakan lap kering atau dijemur di bawah sinar matahari kemudian diguntinggunting (c ) sampai ukuran kecil (d)

3) Sampah plastik di masukkan ke dalam botol sambil ditekan-tekan dengan stik kayu untuk memadatkan plastik di dalam botol (Gambar 5).

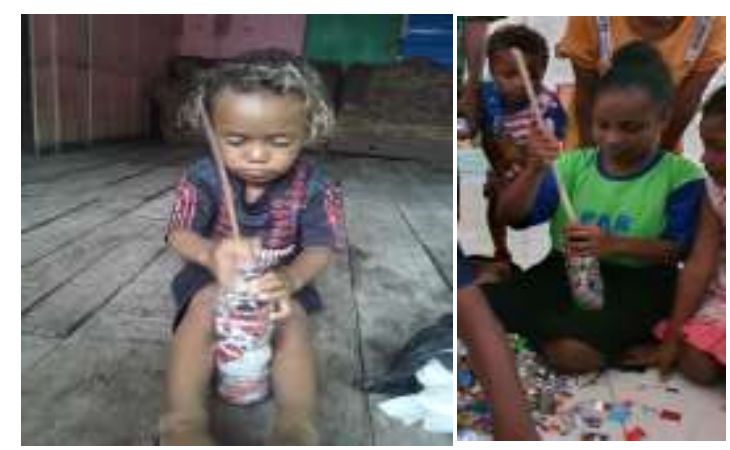

Gambar 5. Sampah plastik dimasukkan ke dalam botol dan ditekan-tekan dengan stik kayu sampai padat, dan plastik ditambahkan terus sampai ecobricks mencapai berat yang dianjurkan.

4) Ecobricks ditimbang, Botol air mineral $600 \mathrm{ml} \sim 200$ gram, sedangkan botol air mineral $1,5 \mathrm{~L} \sim 500$ gram. Pada pengabdian ini digunakan botol ukuran $600 \mathrm{ml}$ (Gambar 6, Gambar 7).

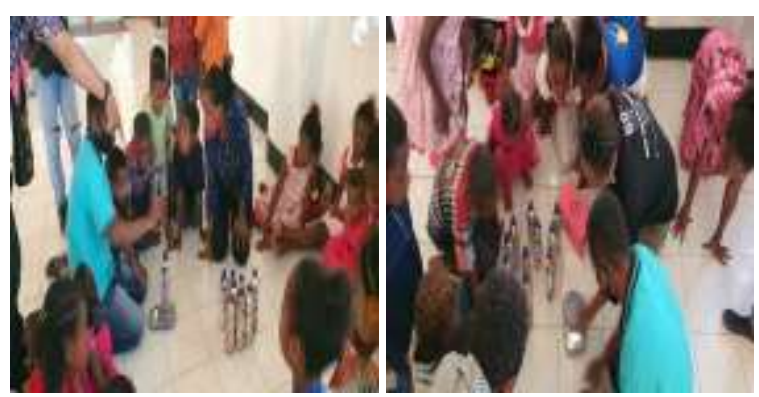

Gambar 6. Ecobricks ditimbang. Selama satu minggu, 6-11 Oktober 2020 anakanak membuat ecobricks secara mandiri dan pada pertemuan kedua, 12 Oktober 2020, ecobricks ditimbang untuk mengetahui apakah ecobricks sudah mencapau berat yang dianjurkan atau tidak. 

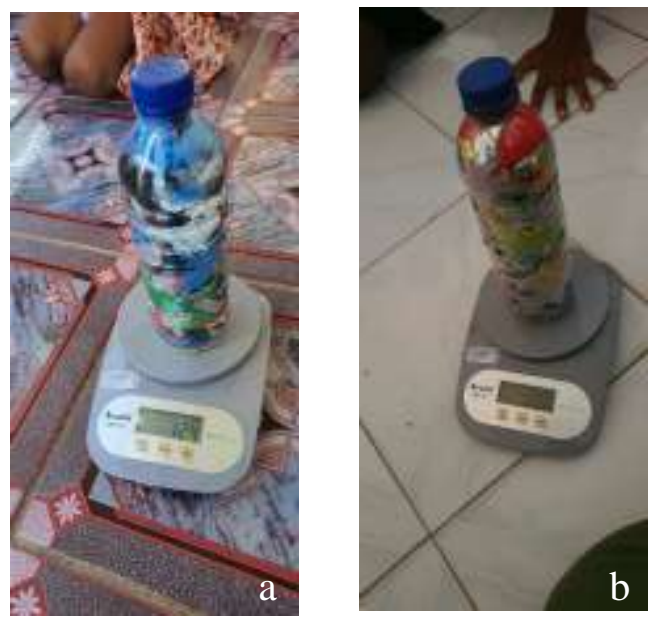

Gambar 7. Ecobricks ditimbang. Jika beratnya belum mencapai 300 gram (a) maka plastik harus ditmbahkan sampai mencapai berat 200 gram (b).

5) Botol air mineral di tutup dan dipasangkan label (nama, tanggal, berat) (Gambar 8)

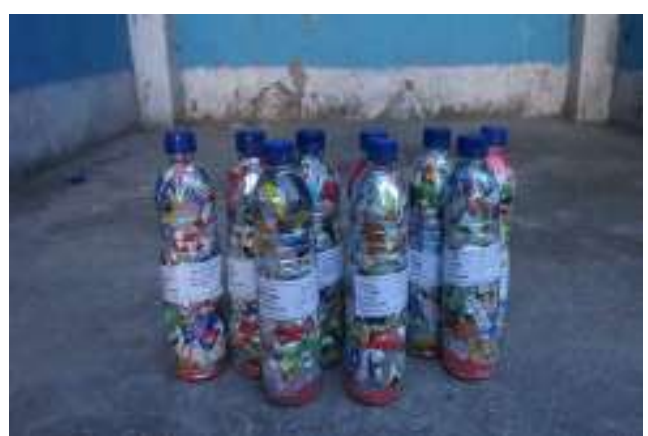

Gambar 8. Ecobricks yang sudah jadi dan beratnya sesuai yang dianjurkan (botol 600 200 gram) dan dipasangkan label.

6) Proses yang sama, tahap $1-6$, diulang untuk ecobricks berikutnya.

7) Ecobricks dikumpulkan dan dibuatkan gugusan modular yang dapat terdiri dari 12 ecobricks, 16 ecobricks dan 19 ecobricks yang dapat dibentuk menjadi bangku, kursi, meja dan perabotan atau bangunan lain yang diinginkan. Pada pengabdian ini dibuatkan bangku oleh kelompok-kelompok anak-anak di Kampung Ayapo (Gambar 9).

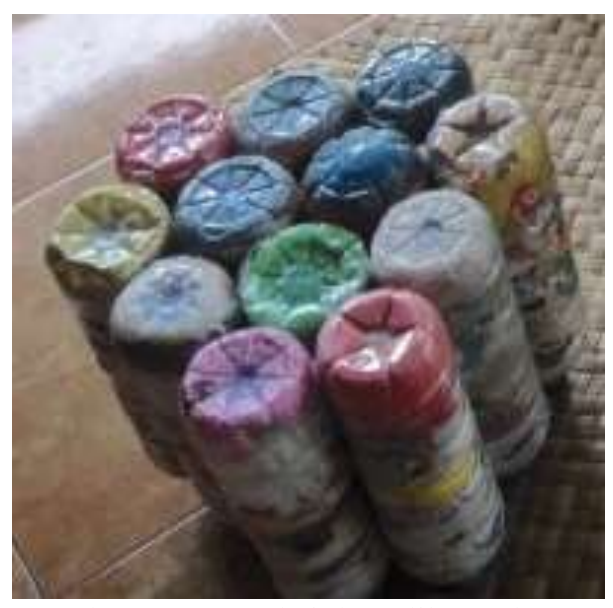

Gambar 9. Ecobricks dibentuk menjadi bangku

Tahap 1 dilaksanakan pada pertemuan pertama, 5 Oktober 2020, sedangkan tahaptahap 2.1 - 2.3 dilakukan oleh anak-anak secara mandiri di rumah didampingi guru-guru pada tanggal 6-11 Oktober 2020. Pada pertemuan kedua, 12 Oktober 2020, tahap 2.4 - 2.5 dilaksanakan. Setelah pertemuan kedua, anakanak melanjutkan mengumpulkan sampah di lingkungannya untuk membuat lebih banyak ecobrick untuk dibentuk menjadi bangku (tahap 2.6).

Anak-anak di Kampung Ayapo secara sadar dan mandiri setelah diberikan pengarahan mengenai pembuatan ecobricks, melakukan pengumpulan sampah plastik di sekeliling Kampung Ayapo. Walaupun tidak semua limbah plastik dikumpulkan dan dimanfaatkan, akan tetapi gerakan ini sudah dimulai dan diharapkan akan dilanjutkan oleh anak-anak secara mandiri setelah program pengabdian berakhir. Jika gerakan ini bisa dilanjutkan maka diharapkan limbah plastik tidak dibuang ke lingkungan atau dibakar, tetapi dikumpulkan untuk dibuat ke ecobricks.

Gerakan pembuatan ecobricks di Indonesia berkembang baik. Berbagai kelompok masyarakat dan sekolah dari usia anak-anak sampai dewasa dapat membuat ecobricks (Apriyani, et al., 2020, Palupi et al., 2020, Istiningdias, et al., 2019, Lestari, et al. 2019, Widodo, et al., 2018, Fitriani \& Asih, 2019). Banyak contoh kelompok-kelompok masyarakat yang telah membuat ecobricks yang kemudian dibentuk menjadi berbagai benda yang dapat digunakan sehari-hari. Kelompok anak-anak, pemuda dan dewasa baik di sekitar Danau Sentani maupun masyarakat yang 
bermukim di daratan sekeliling Danau Sentani dapat melakukan hal ini sehingga sampah plastik tidak dibuang ke lingkungan sehingga menimbulkan polusi dan masalah terhadap lingkungan. Proses pembuatan ecobricks sangat sederhana, sehingga siapapun dapat membuatnya dan produknya bisa dimanfaatkan untuk kebutuhan sehari-hari, seperti bangku, meja, pembatas taman dan lain sebagainya (Gambar 10).

Pembuatan ecobrick dari limbah sampah yang dibuang ke Danau Sentani dapat mengurangi sampah yang mengotori dan berbahaya bagi organisme danau. Juga mengurangi cara memusnahkan plastik yang biasa dilakukan masyarakat dengan membakar sehingga menghindari bahaya dari pembakaran sampah plastik (Verma et al., 2016). Ecobricks baru diperkenalkan kepada anak-anak, namun antusiasme yang tinggi dalam mengikuti program ini, diharapkan mereka dapat melanjutkan secara mandiri untuk mengatasi masalah sampah bagi ekosistem perairan, khususnya di Kampung Ayapo, Kabupaten Jayapura, Provinsi Papua.

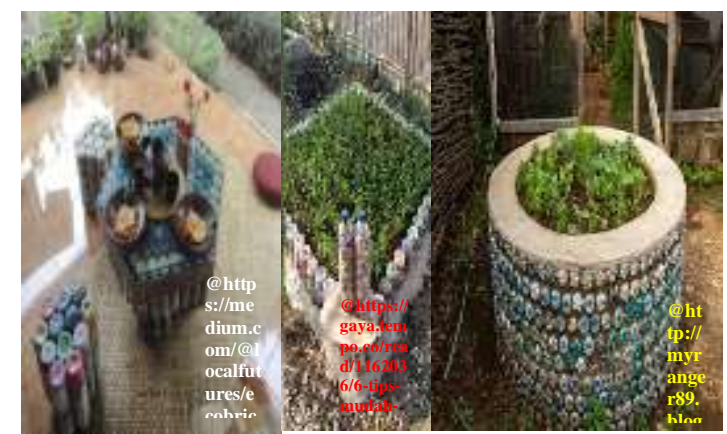

Gambar 10. Contoh-contoh produk yang dibuat dari ecobricks

\section{Kesimpulan dan Saran}

Ecobricks adalah salah satu cara pemanfaatan sampah plastik menjadi produk yang berguna. Proses pembuatannya sederhana sehingga mudah dipahami dan dilakukan oleh anak-anak di Kampung Ayapo, Jayapura, Papua. Anak-anak secara mandiri dapat mengulang tahap-tahapan pembuatan ecobricks dan membuatnya menjadi beberapa ecobrick yang dibentuk menjadi bangku. Pembuatan ecobricks mengurangi sampah plastik di Kampung Ayapo, walaupun proporsi nya sangat kecil dan mengurangi sampah plastik yang dibakar karena berbahaya bagi manusia.
Pemanfaatan limbah plastik menjadi ecobricks mudah dilakukan oleh kelompok masyarakat dari usia dini-dewasa. Oleh karena itu, anak-anak di Kampung Ayapo diharapkan menjadi pioner untuk gerakan buat ecobricks di kampungnya. Juga, pihak pelaksana (Jurusan Biologi, FMIPA, UNCEN) tetap memantau tindak lanjut dari pembuatan ecobricks di Kampung Ayapo, sehingga diharapkan akan ada kelompok yang tetap memanfaatkan plastik menjadi ecobricks.

\section{UCAPAN TERIMAKASIH}

Pengabdian ini tidak akan terlaksana tanpa hibah dana pengabdian PNBP LPPM UNCEN tahun 2020 dengan no. kontrak 140.UN20.2.1/AM/2020. Terimakasih kami sampaikan kepada LPPM UNCEN yang telah membantu pelaksana dari pengajuan proposal, pelaksanaan dan pembatan laporan pengabdian ini. Berikut, terimakasih kepada warga Kampung Ayapo, khususnya anak yang mengijinkan kami melaksanakan pengabdian dan terlibat dalam pengabdian ini. Terakhir, terimakasih kepada para mahasiswa S1 dan S2 Jurusan Biologi, FMIPA, UNCEN dan aktivis Earth Hour Papua serta semua pihak yang telah membantu dalam kegiatan pengabdian ini.

\section{DAFTAR PUSTAKA}

Apriyani, A., M. M. Putri, \& S. Y. Wibowo. 2020. Pemanfaatan Sampah Plastik Menjadi Ecobrick. Masyarakat Berdaya Dan Inovasi, 1(1), 48-50.

Badan Pusat Statistik (BPS) Kabupaten Jayapura. 2018. Kabupaten Jayapura dalam Angka 2018. Jayapura.

BAPEDALDA (Badan Pengendalian Dampak Lingkungan Daerah) Provinsi Papua dan LPPM-ITB. 2004. Laporan Akhir Studi ekosistem kawasan Danau Sentani Proyek Pengendalian Kerusakan Sumberdaya Alam kawasan perbatasan di Kabupaten Jayapura, Merauke, dan Jayawijaya. Bandung, Indonesia.

Cable, R. N., D. Beletsky, R. Beletsky, K. 
Wigginton, B. W. Locke, \& M. B. Duhaime. 2017. Distribution and modeled transport of plastic pollution in the Great Lakes, the world's largest freshwater resource. Frontiers in Environmental Science, 5(JUL), 1-18. https://doi.org/10.3389/fenvs.2017.00 045

Conservation International. 1999. Laporan akhir lokakarya penentuan prioritas konservasi keanekaragaman hayati Irian Jaya. washington DC, USA.

Fitriani, S., \& H. M. Asih. 2019. Metode Full Costing sebagai Dasar Penentuan Harga Produk Kreasi Sampah Eecobrick. 6(1), 65-69.

Galafassi, S., L. Nizzetto, \& P. Volta. 2019. Plastic sources: A survey across scientific and grey literature for their inventory and relative contribution to microplastics pollution in natural environments, with an emphasis on surface water. Science of the Total Environment.

https://doi.org/10.1016/j.scitotenv.201 9.07.305

Gall, S. C., \& R. C. Thompson. 2015. The impact of debris on marine life.

Marine Pollution Bulletin, 92(1-2), 170-179.

https://doi.org/10.1016/j.marpolbul.20 14.12.041

Geyer, R., J. R. Jambeck, \& K. L. Law. 2017. Production, use, and fate of all plastics ever made. Science Advances, 3(7), 25-29.

https://doi.org/10.1126/sciadv.170078 2

Global Ecobricks Alliance. (n.d.).

Retrieved October 31, 2020, from www.ecobricks.org

Ilyas, M., W. Ahmad, H. Khan, S. Yousaf, K. Khan, \& S. Nazir, 2018. Plastic waste as a significant threat to environment - A systematic literature review. Reviews on Environmental Health, 33(4), 383-406. https://doi.org/10.1515/reveh-20170035

Indrayani, E., K. H. Nitimulyo, S. Hadisusanto, \& Rustadi. 2015. Peta batimetri Danau Sentani Papua. DEPIK. https://doi.org/10.13170/depik.4.3.27 23

Istiningdias, D. S., D. N. Azijah, \& G. Argenti. 2019. Peningkatan Peran Aktif Aparatur Desa Dan Partisipasi Masyarakat Dalam Upaya Pelestarian Lingkungan Melalui Pelatihan Pembuatan Ecobricks. Kumawula: Jurnal Pengabdian Kepada Masyarakat, 2(2), 183-191. https://doi.org/10.24198/kumawula.v2 i2.24406

Jambeck, J., B. D. Hardesty, A. L. Brooks, T. Friend, K. Teleki, J. Fabres, ... C. Wilcox. 2018. Challenges and emerging solutions to the land-based plastic waste issue in Africa. Marine Policy, 96(October 2017), 256-263. https://doi.org/10.1016/j.marpol.2017. 10.041

Jambeck, J. R., R. Geyer, C. Wilcox, T. R. Siegler, M. Perryman, R. Narayan, \& K. L. Law. 2015. Plastic waste inputs from land into the ocean. Science, 347, 768-771.

Lebreton, L., \& A. Andrady. 2019. Future scenarios of global plastic waste generation and disposal. Palgrave Communications, 5(1), 1-11. https://doi.org/10.1057/s41599-0180212-7

Lestari, W., N. Siregar, \& S. Hartini. 2019. Edukasi Ecobricks berbasis cinta lingkungan sebagai solusi 
pengelolaan sampah di Medan Marelan. KUAT : Keuangan Umum Dan Akuntansi Terapan. https://doi.org/10.31092/kuat.v1i3.62 7

Newaj, N., \& M. H. Masud. 2014. Utilization of Waste Plastic to Save the Environment. Icmiee-Pi-140291, 1-4. Retrieved from http://www2.kuet.ac.bd/icmiee2014/w p-content/uploads/2015/02/ICMIEEPI-140291.pdf

Ngamelubun, G. 2017. Hubungan kualitas air dengan struktur komunitas ikan di Danau Sentani Jayapura. Universitas Cenderawasih.

Ohee, H.L., S. Br. Surbakti, \& P. Surjarta. 2018. Ekobiologi ikan red devil (Amphilophus labiatus, Günther 1864) dan ancamannya terhadap ikan-ikan asli Danau Sentani Papua. Jayapura, Papua.

Ohee, H. L. 2013. The Ecology of the Red Rainbowfish (Glossolepis incisus) and the Impact of Human Activities on Its Habitats in Lake Sentani, Papua (Georg-August Universität). Retrieved from https://ediss.unigoettingen.de/bitstream/handle/11858 /00-1735-0000-0001-BBC83/Dissertation.pdf? sequence $=1$

Ohee, H. L., P. Sujarta, S. Br Surbakti, \& H. Barclay, 2018. Rapid expansion and biodiversity impacts of the red devil cichlid (Amphilophus labiatus, Günther 1864) in Lake Sentani, Papua, Indonesia. Biodiversitas, 19(6), 2096-2103. https://doi.org/10.13057/biodiv/d1906 15

Palupi, W., S. Wahyuningsih, E. Widiyastuti, N. E. Nurjanah, \& A. R. Pudyaningtyas. 2020. Pemanfaatan Ecobricks Sebagai Media
Pembelajaran Untuk Anak Usia Dini. DEDIKASI: Community Service Reports, 2(1), 28-34. https://doi.org/10.20961/dedikasi.v2i1 .37624

Polhemus, D. A., Englund, R. A., \& G. R. Allen. 2004. Freshwater Biotas of New Guinea and nearby Islands : Aanalysis of endemism, rishness, and threats. washington DC, USA.

Tupen, G.P., F.N.R. Kurnianingtyas, \& H. L. Ohee 2016. Komposisi jenis ikan yang dilindungi, dilarang dan invasive di Perairan Danau Sentani. Papua Journal of Development and Innovation, 6(2), 97-110.

Umar, C., E. S. Kartamihardja, D. W. H. Tjahyo, Mujianto, L. P. Astuti, Y. Sugianti, N. Widarmanto, S. Romdom, U. Sukandi, \& E. Kosasih. 2005. Laporan tahunan identifikasi dan karakteristik habitat dan populasi ikan di Danau Sentani Propinsi Papua. Jakarta, Indonesia.

Umar, C., \& S. Makmur. 2006. Komposisi jenis dan hasil tangkapan ikan di Danau Sentani Papua. Biodiversitas, Journal of Biological Diversity, 7(4), 349-353. https://doi.org/10.13057/biodiv/d0704 10

van Sebille, E., C. Wilcox, L. Lebreton, N. Maximenko, B. D. Hardesty, J. A. van Franeker, \& K. L. Law. 2015. A global inventory of small floating plastic debris. Environmental Research Letters, 10(12). https://doi.org/10.1088/17489326/10/12/124006

Verma, R., K. S.Vinoda, M. Papireddy, \& A. N. S. Gowda. 2016. Toxic Pollutants from Plastic Waste- A Review. Procedia Environmental Sciences, 35, 701-708. 
Jurnal Pengabdian Multidisiplin

https://doi.org/10.1016/j.proenv.2016.

07.069

Widodo, S., N. N. N. Marleni, \& N. A.

Firdaus. 2018. Pelatihan Pembuatan

Paving Block dan Eco-Bricks dari

Limbah Sampah Plastik di Kampung

Tulung Kota Magelang. Community

Empowerment, 3(2), 63-66.

https://doi.org/10.31603/ce.v3i2.2460 